\title{
What have we learned from clinical trials in primary Sjögren's syndrome about pathogenesis?
}

\author{
Cees GM Kallenberg ${ }^{1 *}$, Arjan Vissink², Frans GM Kroese', Wayel H Abdulahad' and Hendrika Bootsma'
}

\begin{abstract}
In vitro and in vivo experimental data have pointed to new immunopathogenic mechanisms in primary Sjögren's syndrome (pSS). The availability of targeted treatment modalities has opened new ways to selectively target these mechanistic pathways in vivo. This has taught us that the role of proinflammatory cytokines, in particular TNFa, is not crucial in the immunopathogenesis of pSS. B cells appear to play a major role, as depletion of $B$ cells leads to restoration of salivary flow and is efficacious for treatment of extraglandular manifestations and mucosa-associated lymphoid tissue lymphoma. B cells also orchestrate T-cell infiltration and ductal epithelial dearrangement in the salivary glands. Gene profiling of salivary gland tissue in relation to B-cell depletion confirms that the axis of IFNa, B-cell activating factor, B-cell activation, proliferation and survival constitutes a major pathogenic route in pSS.
\end{abstract}

\section{Introduction}

Primary Sjögren's syndrome (pSS) is a systemic autoimmune disease primarily characterized by chronic inflammation of the exocrine glands, in particular the salivary and lacrimal glands. Extraglandular manifestations occur in many patients and may involve almost any organ. B-lymphocyte hyperactivity in pSS is manifested by the presence of anti-SS-A and anti-SS-B antibodies, rheumatoid factor, type 2 cryoglobulins, and hypergammaglobulinemia. Prolonged B-cell survival and excessive B-cell activity, probably related to increased production of B-cell activating factor (BAFF) [1], may even lead to mucosa-associated lymphoid tissue lymphomas occurring in 5\% of Sjögren's syndrome (SS) patients [2,3].

\footnotetext{
*Correspondence: c.g.m.kallenberg@reuma.umcg.nl

'Department of Rheumatology and Clinical Immunology, AA21, University Medical Center Groningen, P.O. Box 30.001, 9700 RB Groningen, The Netherlands

Full list of author information is available at the end of the article
}

Despite systemic B-cell hyperactivity, analysis of lesional tissue in the salivary glands shows a predominance of $\mathrm{T}$ lymphocytes surrounding ductal epithelial cells. The majority of these $\mathrm{T}$ cells (70 to 80\%) are CD4-positive and show an activated phenotype. CD8-positive T cells with cytotoxic activity, as manifested by their expression of granzymes, constitute around 10\% of infiltrating cells. The remaining infiltrating cells are B lymphocytes [4].

These data demonstrate that, on the one hand, systemic B-cell hyperactivity is a dominant feature of pSS, but that, on the other, T lymphocytes targeting glandular epithelial cells are involved in lesion development. As mentioned above, the majority of these $\mathrm{T}$ cells are CD4-positive and express cytokines, such as IFN $\gamma$ and TNF $\alpha$, classically considered characteristic for Th1 cells. Lesional tissue also shows B-cell activity, however, among others in terms of local production of anti-SS-A and anti-SS-B autoantibodies and formation of ectopic germinal centerlike structures. Th2 cytokines, such as IL- 6 and IL-10, are also present. Furthermore, local IFN $\alpha$ production has been demonstrated that induces expression of BAFF by both infiltrating cells, such as monocytes and dendritic cells, and resident epithelial cells. Local production of BAFF may underlie B-cell hyperactivity and prolonged Bcell survival.

The complexity of the pathogenetic pathways involved in pSS as described above, and as further elaborated in a number of excellent reviews [5-7], makes it difficult to define which effector mechanisms are fundamental for development, persistence and progression of the inflammatory process in the exocrine glands of patients with pSS. During the past two decades, biologicals have become available that target specific cells or cytokines that are instrumental in physiological or pathological immune responses. Targeting and elimination of certain cells or cytokines may indicate their specific role in lesion development in pSS. The current review will discuss what clinical trials with biologicals have taught us about the pathogenesis of pSS. Attention will be given not only to the direct clinical results of these trials, but also to the mechanistic effects of these biologicals on pathways considered to be involved in the (immuno)pathogenesis of pSS. Table 1 presents a 
Table 1. Biologicals and targets that are used or potentially may be used in primary Sjögren's syndrome

\begin{tabular}{|c|c|c|c|c|}
\hline Target & Biological & Structure & Results trials & References \\
\hline TNFa & Infliximab & Chimeric $\lg \mathrm{G}_{1} \mathrm{mAb}$ & No effect in RCT & [15] \\
\hline \multirow[t]{2}{*}{ TNFa } & Etanercept & TNF-Rec1-Fc lgG fusion protein & No effect in (small-size) RCT & {$[17,18]$} \\
\hline & IFNa & Recombinant $\mathrm{IFNa}_{2 \mathrm{a}}$ & Increase in unstimulated whole saliva flow (RCT) & [32] \\
\hline IFNa & Rontalizumab & Recombinant human mAb & Not performed & \\
\hline CD20 B cells & Rituximab & Chimeric $\lg \mathrm{G}_{1} \mathrm{mAb}$ & $\begin{array}{l}\text { Subjective and objective improvement of salivary } \\
\text { flow (RCT), decrease in fatigue (RCT) }\end{array}$ & {$[39,40]$} \\
\hline CD22 B cells & Epratizumab & Recombinant human mAb & $\begin{array}{l}\text { Increase in unstimulated whole saliva, decrease in } \\
\text { fatigue }\end{array}$ & [45] \\
\hline BAFF & Belimumab & Recombinant human mAb & In progress & \\
\hline BAFF & Atacicept & TACl-Fc lgG, fusion protein & Not performed & \\
\hline BAFF & Briobacept & BAFF-Rec-Fc lgG, fusion protein & Not performed & \\
\hline CD28-mediated co-stimulation & Abatacept & CTLA4-Fc $\lg G$ fusion protein & In progress & \\
\hline
\end{tabular}

BAFF, B-cell activating factor; CTLA4, cytotoxic T-lymphocyte antigen 4; mAb, monoclonal antibody; RCT, randomized controlled trial; Rec, receptor ; TACI, transmembrane activator and calcium-modulating cyclophilin ligand interactor.

summary of the biologicals that are used, or potentially might be used, to treat pSS.

\section{Targeting tumor necrosis factor}

As mentioned above, CD4-positive T cells - expressing, among others, TNF $\alpha$ - are abundantly present in the salivary glands of patients with pSS. Other proinflammatory cytokines are also overexpressed in salivary glandular tissue [8]. Furthermore, levels of various proinflammatory cytokines, including TNF $\alpha$, are elevated in peripheral blood and tears of patients with pSS $[9,10]$. In addition to its proinflammatory and immunomodulatory function, TNF $\alpha$ is also involved in direct induction of cell death. Indeed, in vitro studies have demonstrated the potential of TNF inhibitors to block TNF $\alpha$-mediated apoptosis of salivary gland epithelial cells [11]. The localization of TNF $\alpha$-expressing CD4positive $\mathrm{T}$ cells around ductal epithelial cells also suggests their involvement in epithelial cell apoptosis. Targeting TNF $\alpha$ in $\mathrm{pSS}$ thus seems justified.

Infliximab is a therapeutically applied chimeric monoclonal $\mathrm{IgG}_{1}$ antibody directed against TNF $\alpha$. A singlecenter, open-label pilot study in 16 patients with pSS treated with infliximab (three infusions of $3 \mathrm{mg} / \mathrm{kg}$ at 0,2 , and 6 weeks) showed improvement in subjective and objective assessments of glandular function after 12 weeks [12]. With the exception of a slight decrease in the erythrocyte sedimentation rate, no significant changes in immunological parameters were noted. No repeat biopsies were performed to demonstrate an effect on glandular tissue. Ten out of the 16 patients were treated with additional infusions of infliximab for a period of 1 year, resulting in a persistent positive effect on global and local disease manifestations without proof of histopathological or immunological changes in disease activity [13].
In a further study, four patients underwent labial salivary gland biopsies before and 10 weeks after infliximab treatment. No change in focus score was reported, but the distribution of aquaporin-5, abnormally localized at the apical and basolateral membranes of the acinar epithelial cells, was restored to localization mainly at the apical membranes [14]. Aquaporin-5 is involved in passage of cellular water to the lumen of the acinus, and abnormal distribution of aquaporin-5 - as seen in pSS patients - has therefore been suggested to contribute to decreased salivary flow. Indeed, restoration of normal aquaporin- 5 distribution as a consequence of treatment with TNF inhibitors coincided with increase of salivary flow.

Following these pilot studies, a randomized controlled trial with infliximab was performed on 103 patients with pSS [15]. Patients received $5 \mathrm{mg} / \mathrm{kg}$ infliximab at weeks 0 , 2 , and 6 , and were followed for 22 weeks. This trial did not show any effect of infliximab compared with placebo on global and both subjective and objective manifestations of pSS. No changes were seen in the erythrocyte sedimentation rate and C-reactive protein levels. Only a slight but significant increase in levels of IgM was observed in the infliximab group. In 57 out of the 103 patients, labial salivary gland biopsies were performed at baseline and week 10 . No change in focus score was seen although a detailed analysis of the histopathology was not presented. Of note, also in patients with pSS of recent onset, no changes were documented. Apparently, TNF $\alpha$ does not play a significant role in the pathogenesis of pSS, not at the level of the exocrine glands nor on extraglandular manifestations including arthritis. Indeed, TNF deficiency fails to protect development of sicca features in a murine model of pSS consisting of BAFF-transgenic mice [16]. These data confirm that TNF, apparently, is not a major pathogenic factor in $\mathrm{pSS}$. 
Two additional studies using another TNF blocking agent, etanercept, in patients with pSS reached the same conclusion: no effect of blocking TNF was seen in these small-sized controlled studies $[17,18]$. To explain this lack of efficacy of etanercept, Moutsopoulos and colleagues analyzed serum cytokine levels and cellular markers of immune activation in pSS patients treated with etanercept [19]. They observed that serum TNF $\alpha$ levels were not related to glandular focus scores and that etanercept treatment did not restore abnormal immune parameters; in contrast, levels of circulating TNF $\alpha$ increased following treatment. In addition, IFN $\alpha$ activity and BAFF levels also increased following treatment, which may explain the lack of efficacy of blocking TNF $\alpha$ in pSS [20]. The role of IFN $\alpha$ is discussed in the next section.

\section{IFNa in primary Sjögren's syndrome: a double- edged sword?}

There is increasing interest in the role of IFN $\alpha$ in pSS. First, case reports have mentioned the development of pSS following treatment of chronic viral infections, in

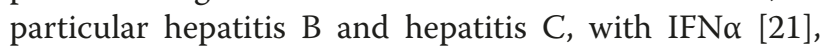

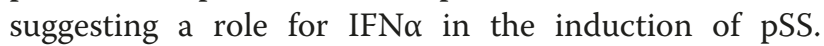
Indeed, IFN $\alpha$ levels have been reported to be increased in plasma of patients with pSS; IFN $\alpha$ mRNA levels were increased in their peripheral blood cells, and IFN $\alpha$ positive lymphocytes and epithelial cells were detected in their labial salivary glands [22,23]. The source of interferon is probably the recruitment of plasmacytoid dendritic cells to the salivary glands, as shown by Gottenberg and colleagues [24]. Sera from pSS patients also have high type 1 interferon bioactivity, demonstrated by their capacity to induce expression of type 1 interferonregulated genes in a monocytic cell line, whereas monocytes of pSS patients showed increased expression of interferon-inducible genes [25].

The origin of this increased IFNa production is not clear, but Lövgren and colleagues demonstrated that immune complexes or liposomes containing hY1RNA, the target of anti-SS-A antibodies, were able to induce IFN $\alpha$ production by monocytes and plasmacytoid dendritic cells [26]. Importantly, Ittah and colleagues subsequently demonstrated that IFN $\alpha$ stimulation of salivary gland epithelial cells of patients with pSS increased BAFF mRNA expression in these cells significantly more than in control salivary gland epithelial cells [27]. Stimulation with proinflammatory cytokines resulted in a comparable increase in mRNA expression of BAFF in patient cells and control cells. These data suggest an increased susceptibility of pSS glandular epithelial cells for IFN $\alpha$. Increased BAFF production plays a major role in pSS pathogenesis, as discussed later. Based on these data, interference in pSS with monoclonal antibodies to IFNa seems a rational approach. Monoclonal antibodies to IFN $\alpha$ are currently available and clinical trials in systemic lupus erythematosus and dermatomyositis/polymyositis are underway. There are strong arguments, as discussed above, to design clinical trials with these monoclonal antibodies in pSS.

Surprisingly, instead of targeting this proinflammatory cytokine, IFN $\alpha$ itself has been used as a therapeutic agent in pSS. Shiozawa and colleagues found an increase in saliva production following IFN $\alpha$ treatment $\left(1 \times 10^{6} \mathrm{U}\right.$ intramuscularly weekly) for 3 months in six pSS patients [28]. Comparable findings were obtained in another study on 20 pSS patients in which IFN $\alpha$ was compared with hydroxychloroquine; lacrimal and salivary function improved by $67 \%$ and $61 \%$, respectively, in the IFN $\alpha$ group and by $15 \%$ and $18 \%$, respectively, in the hydroxychloroquine group [29]. In a second controlled study in 60 pSS patients, Shiozawa and colleagues used oral IFN $\alpha$ (150 IU, three times daily) for 6 months [30]. A significant increase in saliva production was observed. Furthermore, serial labial salivary gland biopsies in nine patients showed a decrease in lymphocytic infiltration. These data were confirmed in a phase II clinical trial in which oral IFN $\alpha$ (in lozenges of 150 IU three times daily) improved stimulated whole saliva production during a 12-week period [31].

This latter study was followed by a phase III random-

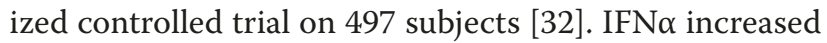
unstimulated whole saliva flow but no significant increase was noted in stimulated whole saliva flow and oral dryness. It is not clear how the increase in salivary flow following IFN $\alpha$ treatment can be explained. The authors refer to a study in which incubation of parotid glandular tissue with IFNa led to increased expression of aquaporin-5, which is involved, as discussed before, in passage of water to the lumen of the acinus [33]. Improvement of the physiological routes involved in saliva production via IFN $\alpha$ might therefore possibly underlie the observed outcomes in IFN $\alpha$ trials. An immunomodulatory effect of IFN $\alpha$ has not been convincingly demonstrated.

\section{B-cell-depleting treatment in primary Sjögren's syndrome}

As noted before, B-cell hyperactivity is a major finding in pSS. Although the direct pathophysiological role of $\mathrm{B}$ cells in glandular tissue destruction in pSS has not been fully elucidated, B-cell-targeted treatment has been proposed as a therapeutic modality in pSS [34]. Most B-cell-depleting therapies target CD20, expressed on $B$ cells from the stage of pre-B cells until the stage of activated B cells but not on plasma cells.

An open-label phase II study with the anti-CD20 monoclonal antibody rituximab (four weekly infusions of $375 \mathrm{mg} / \mathrm{m}^{2}$ ) in eight patients with early pSS and in seven 
patients with pSS and mucosa-associated lymphoid tissue lymphoma showed improvement, both subjective and objective, in salivary gland function [35]. An increase in saliva secretion occurred only in patients with residual saliva production (Figure 1). Despite full depletion of CD19-positive B lymphocytes from the peripheral blood, levels of immunoglobulins did not change - but a significant decrease in IgM rheumatoid factor was seen. The percentage and state of activation of T-cell subsets did not change. Peripheral blood B cells had returned after 36 weeks (but were still below baseline) and salivary flow, after initial significant improvement, had declined to just above baseline at 48 weeks [36].

Retreatment with rituximab resulted in a clinical and biological response fully comparable with that of the initial treatment effect [36]. In five patients, four of whom showed an increased salivary flow rate following treatment, parotid biopsies were performed before and 12 weeks after treatment [37]. Histopathological analysis of the biopsies showed a strong reduction of the lymphocytic infiltrate with (partial) disappearance of germinal center-like structures. The $\mathrm{B}$ cell/ $\mathrm{T}$ cell ratio decreased, indicating a higher reduction in B cells than in $\mathrm{T}$ cells, but $\mathrm{B}$ cells were not completely depleted despite full depletion from the peripheral blood. Intraepithelial lymphocytes in the ducts and the amount and extent of lymphoepithelial lesions decreased, demonstrating reduction in $\mathrm{T}$ lymphocytes as well. Most interestingly, cellular proliferation of acinar parenchyma decreased after treatment, sometimes resulting in normal acinar structures (Figure 2). These data demonstrate that B-cell depletion via rituximab not only reduces $B$ cells in the diseased glands, but also influences the presence of infiltrated effector $\mathrm{T}$ cells - so allowing restoration, at least in part, of the architecture of the ducts and acini. This observation strongly argues for a major role, if not a primary role, of B cells in the pathogenesis of pSS.

Following these initial studies several, in part controlled, trials - although small in size - have confirmed the efficacy of rituximab in pSS. DevauchellePensec and colleagues treated $16 \mathrm{pSS}$ patients with two infusions of rituximab $\left(375 \mathrm{mg} / \mathrm{m}^{2}\right)$ and noted a decrease of subjective complaints of dryness, fatigue and arthralgia [38]. B cells were strongly reduced in the peripheral blood and labial salivary glands but the focus score in the gland did not change and neither did the authors observe an increase in salivary flow, possibly because of the already long history of pSS in these patients. Lack of salivary flow restoration following rituximab treatment was also observed in the study by Pijpe and colleagues in pSS patients with longstanding disease and low levels of salivary flow [35]. Dass and colleagues performed a controlled study on 17 pSS patients with rituximab (1 g twice, 2 weeks apart) and noted a significant decrease in

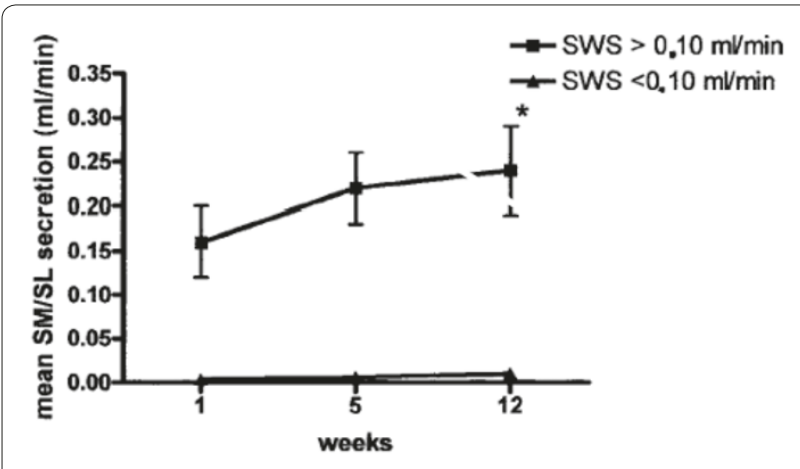

Figure 1. Stimulated whole saliva secretion following rituximab treatment in patients with primary Sjögren's syndrome.

Stimulated whole saliva secretion (SWS) at baseline and at 5 and 12 weeks following rituximab treatment in 14 patients with primary Sjögren's syndrome; an increase in saliva secretion occurred only in patients $(n=9)$ with baseline SWS $>0.10 \mathrm{ml} /$ minute and not in patients $(n=5)$ with baseline secretion $<0.10 \mathrm{ml} /$ minute. SWS consisted of submandibular and sublingual (SM/SL) salivary secretion. Reprinted with permission from [35].

fatigue persisting for at least 6 months [39]. Unstimulated salivary flow did not change in this group with longstanding pSS (median disease duration 7.25 years).

Longstanding pSS leads to further decrease in saliva production (Figure 3), and residual saliva production, as mentioned before (Figure 1), is a prerequisite for an increase in salivary flow following rituximab treatment. B-cell depletion was accompanied by a reduction in rheumatoid factor, but not in levels of immunoglobulins or other autoantibodies. A controlled study on 30 patients with early pSS using two infusions of rituximab (1 g) showed a significant increase in stimulated and unstimulated salivary flow. Again, a decrease in rheumatoid factor but no change in levels of immunoglobulins was noted [40].

All of these studies thus report efficacy of rituximab in reducing fatigue and extraglandular symptoms including arthralgia, whereas an increase in salivary flow is dependent on the residual function of the glands that is related to disease duration. Since unpublished data from our group show that rituximab treatment results in decreased serum levels of proinflammatory cytokines, chemokines and adhesion molecules, B cells may play a major role also in the global symptoms and extraglandular manifestations of pSS.

As mentioned above, studying recurrence of B cells after B-cell depletion by rituximab offers an opportunity to analyze the pathogenic events leading to recurrence of symptoms. Lavie and colleagues reported the role of BAFF in B-cell repopulation after rituximab treatment [41]. They observed an increase of serum BAFF and BAFF mRNA in peripheral blood mononuclear cells. The authors concluded that an increase of serum BAFF is 


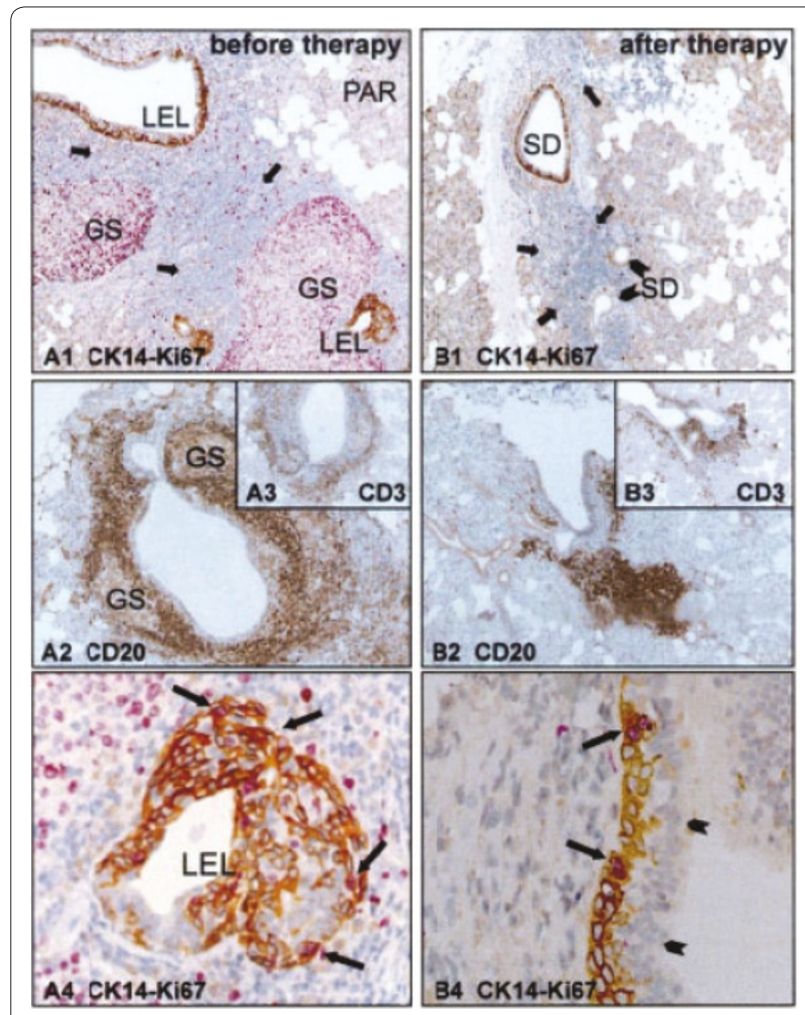

Figure 2. Histopathology of parotid gland before and after treatment with rituximab in primary Sjögren's syndrome. Comparison of parotid biopsy specimens obtained from a primary Sjögren's syndrome (pSS) patient before rituximab therapy (A1 to A4) and 12 weeks after therapy (B1 to AB4). (A1) Before treatment, double staining illustrates intense inflammation (arrows) with highly proliferating, large germinal center-like structures (GS; red nuclear staining for Ki-67), fully developed lymphoepithelial lesions (LEL; brown staining for cytokeratin 14 (CK14)), and reduced glandular parenchyma (PAR). (B1) After treatment, inflammation was reduced (arrows), with the absence of GS and the presence of regular striated ducts (SD) devoid of lymphoepithelial lesions. (A2) Before treatment, there was a dominance of B lymphocytes with GS (CD20) in comparison with T lymphocytes (CD3) (A3). (B2) After treatment, the lymphoid infiltrate overall was reduced, with a slight dominance of T lymphocytes (CD3) (B3) compared with B lymphocytes (CD20). (A4) Higher-magnification view showing fully developed lymphoepithelial lesions with many intraepithelial lymphocytes and increased basal cell proliferation (arrows), in contrast to the SD after therapy with CK14-positive basal cells (B4) (arrows) with regular differentiation into luminal ductal cells devoid of intraepithelial lymphocytes (arrowheads). Original magnification: A1 and B1, x120; $A 2$ and $B 2, \times 100 ; A 3$ and $B 3, \times 60 ; A 4$ and $B 4, \times 200$. Reprinted with permission from [37].

related to disappearance of BAFF receptors after B-cell depletion, and that $B$ cells exert negative feedback on BAFF production by monocytes - explaining the increase of BAFF mRNA in monocytes following B-cell depletion.

The role of BAFF in recruiting (autoimmune) B cells in pSS has been further explored by Pers and colleagues [42]. They observed that serum BAFF levels were inversely correlated with the duration of B-cell depletion. In some patients repeated labial salivary gland biopsies were performed, showing that partial B-cell depletion in the glands persisted for at least 12 months and B cells had recurred at 24 months. Whereas repopulation of the peripheral blood showed increased numbers of mature naïve $\mathrm{B}$ cells (Bm2 cells) and decreased numbers of memory B cells, repopulation of the salivary gland showed memory $\mathrm{B}$ cells and transitional type $1 \mathrm{~B}$ cells as the first $B$ cells to be identified. These memory B cells were speculated to be autoreactive. We also observed delayed recovery of $\mathrm{CD} 27^{+}$memory B cells in the blood 48 weeks after rituximab treatment, whereas the majority of emerging B cells had a phenotype of transitional B cells [43].

A recent study analyzed gene expression profile of labial salivary glands before and after rituximab treatment and related these profiles to the clinical response on rituximab [44]. Interestingly, the authors found two groups of genes higher expressed in responders than in nonresponders. The first group consisted of genes involved in the B-cell signaling pathway and the second group was related to genes involved in the interferon pathway. These data fit the concept of IFN $\alpha$-induced BAFF expression resulting in B-cell hyperactivity and prolonged B-cell survival.

One open-label study targets CD22 on B cells [45]. This molecule has a more or less similar distribution profile to CD20. Treatment of 16 patients with a monoclonal antiCD22 antibody, epratuzumab, resulted in improvement of unstimulated whole saliva production and a decrease in fatigue in one-half of the patients.

In summary, B cells seem to play a major role in orchestrating the pathological immune response in pSS. Depleting B cells offers a unique possibility to study the immunopathogenesis of pSS. BAFF appears as a strong stimulant for B-cell activation and proliferation and for B-cell survival in pSS.

\section{Targeting BAFF in Sjögren's syndrome}

As mentioned before, BAFF plays a major role in pSS. First, mice transgenic for BAFF develop with time a clinical presentation of SS with lymphocytic infiltration of the salivary glands [46]. In these mice, marginal zone B cells, part of them autoreactive, proliferate in the spleen and later infiltrate the salivary glands. Secondly, levels of BAFF are increased in pSS and correlate with titers of anti-SS-A and anti-SS-B antibodies [47]. Thirdly, BAFF is overexpressed in the salivary glands in pSS [48], and BAFF seems to determine B-cell repopulation in the peripheral blood and salivary glands of pSS patients following rituximab treatment [42].

Targeting BAFF in pSS therefore seems logical. Currently, at least three drugs are available for targeting BAFF in pSS. First, belimumab - a monoclonal antibody 


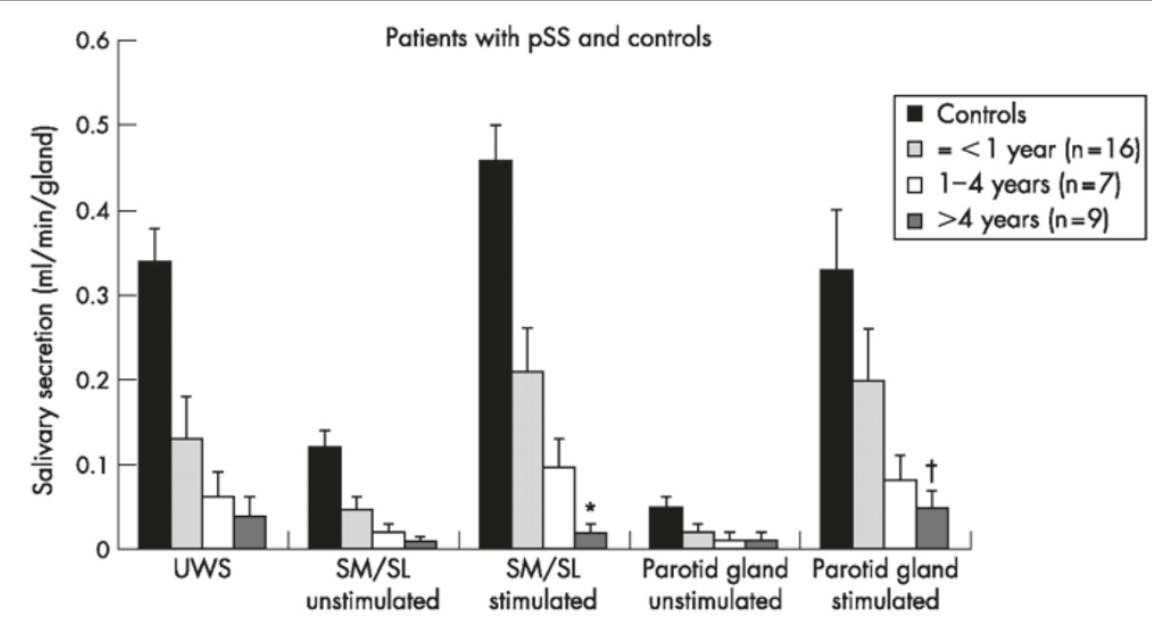

Figure 3. Relationship between disease duration and salivary flow rates in patients with primary Sjögren's syndrome. The relationship between disease duration (the time from first complaints induced by or related to oral dryness until referral) and mean (standard error of the mean) salivary flow rates in primary Sjögren's syndrome (pSS) patients. Normal values are derived from historic controls $(n=36)$. SM/SL, submandibular/ sublingual glands; UWS, unstimulated whole saliva. *Significant difference versus patients with early-onset pSS ( $\leq 1$-year oral complaints; $P<0.005)$ by Mann-Whitney $U$ test. 'Significant difference versus patients with early-onset pSS $(P<0.05)$ by Mann-Whitney $U$ test. Reprinted with permission from [50].

to BAFF - is currently under trial (two studies) in patients with pSS (NCT01160666 and NCT01008982) but data are not yet available. Secondly, atacicept - a fusion molecule of IgG-Fc and the extracellular domain of TACI (the combined receptor for BAFF and Aproliferation-inducing ligand) - has not yet been studied in pSS. Finally, briobacept - a fusion protein of IgG-Fc and the extracellular domain of the BAFF receptor - has not yet been used in clinical trials in pSS. Targeting BAFF using either belimumab, atacicept or briobacept could reveal the pathogenic significance of BAFF in pSS. A hurdle to overcome, however, might be the heterogeneity of BAFF presentation, either as monomers, homotrimers, heterotrimers, splicoforms, or as membrane-bound BAFF. Nevertheless this approach is promising. Furthermore, combining the targeting of BAFF with rituximab treatment could enhance and prolong the effect of rituximab in pSS. Trials with belimumab, atacicept and briobacept in pSS are eagerly awaited.

\section{Targeting co-stimulation in Sjögren's syndrome}

Co-stimulation between antigen-presenting cells and $\mathrm{T}$ cells and between B cells and T cells is an essential step in T-cell-dependent immune responses, including autoimmune responses. Salivary gland epithelial cells in pSS have been shown to express HLA class II and co-stimulatory molecules and may function as antigen-presenting cells in pSS, besides dendritic cells and B cells [49]. Interfering in co-stimulation in pSS could, theoretically, inhibit both systemic and local autoimmune responses in pSS. Abatacept, a fusion molecule of IgG-Fc and cytotoxic
T-lymphocyte antigen 4, modulates CD28-mediated T-cell co-stimulation. A controlled trial with abatacept in pSS has been started in the authors' department, but results of treatment with abatacept in pSS are not yet available.

\section{Conclusion}

Treatment of SS has been only symptomatic for a long time. The increasing availability of targeted treatment modalities has created possibilities for intervention in pathogenic pathways involved in the disease. This availability has not only opened new horizons for treatment, but has also provided insight into the pathogenesis of SS. In contrast to rheumatoid arthritis, the role of proinflammatory cytokines - in particular TNF $\alpha$ - is not very outspoken in SS, as demonstrated by the lack of efficacy of TNF blocking. Otherwise, B cells appear to play a major role in pSS. Depletion of B cells leads to restoration of salivary flow and is effective for extraglandular disease and mucosa-associated lymphoid tissue lymphoma. B cells apparently also orchestrate Tcell infiltration and ductal epithelial dearrangement in

\footnotetext{
Autoimmune Basis of Rheumatic Diseases

This article is part of a series on Sjögren's syndrome, edited by Thomas Dörner, which can be found online at http://arthritis-research.com/ series/Sjögrens

This series forms part of a special collection of reviews covering major autoimmune rheumatic diseases, available at:

http://arthritis-research.com/series/abrd
} 
the glands, as deduced from histopathological studies. A scenario in which the axis of IFN $\alpha$, BAFF, B-cell activation, proliferation and survival constitutes a basic pathogenic mechanism in PSS is supported by the results of intervention studies currently available. Controlled studies targeting IFN $\alpha$ and BAFF are eagerly awaited.

\section{Abbreviations}

BAFF, B-cell activating factor; IFN, interferon; IL, interleukin; pSS, primary Sjögren's syndrome; SS, Sjögren's syndrome; TACl, transmembrane activator and calcium-modulating cyclophilin ligand interactor; Th, T-helper type; TNF, tumor necrosis factor.

\section{Competing interests}

The authors declare that they have no competing interests.

\section{Author details}

'Department of Rheumatology and Clinical Immunology, AA21, University Medical Center Groningen, University of Groningen, P.O. Box 30.001, 9700 RB Groningen, The Netherlands. ${ }^{2}$ Department of Oral and Maxillofacial Surgery, University Medical Center Groningen, University of Groningen, 9700 RB Groningen, The Netherlands.

Published: 28 February 2011

\section{References}

1. Varim MM, Le Pottier L, Youinou P, Saulep D, Mackay F, Pers JO: B-cell tolerance breakdown in Sjögren's syndrome: focus on BAFF. Autoimmun Rev 2010, 9:604-608.

2. Kassan SS, Thomas TL, Moutsopoulos HM, Hoover R, Kimberly RP, Budman DR, Costa J, Decker JL, Chused TM: Increased risk of lymphoma in sicca syndrome. Ann Intern Med 1978, 88:888-892.

3. Baimpa E, Dahabreh U, Voulgarelis M, Moutsopoulos HM: Hematologic manifestations and predictors of lymphoma development in primary Sjögren's syndrome: clinical and pathophysiological aspects. Medicine 2009, 88:284-293

4. Tapinos NI, Polihronis M, Tzioufas AG, Skopouli FN: Immunopathology of Sjögren's syndrome. Ann Med Interne (Paris) 1998, 149:17-24.

5. Mavragani CP, Crow MK: Activation of the type I interferon pathway in primary Sjogren's syndrome. J Autoimmun 2010, 35:225-231.

6. Mariette X, Gottenberg JE: Pathogenesis of Sjögren's syndrome and therapeutic consequences. Curr Opin Rheumatol. 2010, 22:471-477.

7. Hansen A, Lipsky PE, Dörner T: Immunopathogenesis of primary Sjögren's syndrome: implications for disease management and therapy. Curr Opin Rheumatol 2005, 17:558-565

8. Yoon KC, Jeong IY, Park YG, Yang SY: Interleukin- 6 and tumor necrosis factor-alpha levels in tears of patients with dry eye syndrome. Cornea 2007, 26:431-437.

9. Koski H, Janin A, Humphreys-Beher MG, Sorsa T, Malmström M, Konttinen YT: Tumor necrosis factor-alpha and receptors for it in labial salivary glands in Sjögren's syndrome. Clin Exp Rheumatol 2001, 19:131-137.

10. Baturone R, Soto MJ, Márquez M, Macías I, de Oca MM, Medina F, Chozas N, García-Pérez S, Girón-González JA: Health-related quality of life in patients with primary Sjögren's syndrome: relationship with serum levels of proinflammatory cytokines. Scand J Rheumatol 2009, 38:386-389.

11. Sisto M, D'Amore M, Caprio S, Mitolo V, Scagliusi P, Lisi S: Tumor necrosis factor inhibitors block apoptosis of human epithelial cells of the salivary glands. Ann N Y Acad Sci 2009, 1171:407-414

12. Steinfeld SD, Demols P, Salmon I, Kiss R, Appelboom T: Infliximab in patients with primary Sjögren's syndrome. Arthritis Rheum 2001, 44:2371-2375.

13. Steinfeld SD, Demols $P$, Appelboom T: Infliximab in primary Sjögren's syndrome. Arthritis Rheum 2002, 46:3301-3303.

14. Steinfeld SD, Appelboom T, Delporte C: Treatment with infliximab restores normal aquaporin 5 distribution in minor salivary glands of patients with Sjögren's syndrome. Arthritis Rheum 2002, 46:2249-2251.

15. Mariette X, Ravaud P, Steinfeld S, Baron G, Goetz J, Hachulla E, Combe B, Puéchal X, Pennec Y, Sauvezie B, Perdriger A, Hayem G, Janin A, Sibilia J: Inefficacy of Infliximab in primary Sjögren's syndrome. Arthritis Rheum 2004, 50:1270-1276.
16. Batten M, Fletcher C, Ng LG, Groom J, Wheway J, Laâbi Y, Xin X, Schneider P, Tschopp J, Mackay CR, Mackay F: TNF deficiency fails to protect BAFF transgenic mice against autoimmunity and reveals a predisposition to B cell lymphoma. J Immunol 2004, 172:812-822.

17. Sankar V, Brennan MT, Kok MR, Leakan RA, Smith JA, Manny J, Baum BJ, Pillemer SR: Etanercept in Sjögren's syndrome. Arthritis Rheum 2004, 50:2240-2245.

18. Zandbelt MM, de Wilde P, van Damme P, Hoyng CB, van de Putte L, van den Hoogen F: Etanercept in the treatment of patients with primary Sjögren's syndrome: a pilot study. J Rheumatol 2004, 31:96-101.

19. Moutsopoulos NM, Katsifis GE, Angelov N, Leakan RA, Sankar V, Pillemer S, Wahl SM: Lack of efficacy of etanercept in Sjögren's syndrome correlates with failed suppression of tumour necrosis factor alpha and systemic immune activation. Ann Rheum Dis 2008, 67:1437-1443.

20. Mavragani CP, Niewold TB, Moutsopoulos NM, Pillemer SR, Wahl SM, Crow MK: Augmented interferon-a pathway activation in patients with Sjögren's syndrome treated with etanercept. Arthritis Rheum 2007, 50:3995-4004.

21. Onishi S, Nagashima T, Kimura H, Matsuyama Y, Yoshio T, Minota S: Systemic lupus erythematosus and Sjögren's syndrome induced in a case by interferon-alpha used for the treatment of hepatitis C. Lupus 2010, 19:753-755.

22. Zheng L, Zhang Z, Yu C, Tu L, Zhong L, Yang C: Association between IFN-alpha and primary Sjögren's syndrome. Oral Surg Oral Med Oral Pathol Oral Radiol Endod 2009, 107:e12-e18.

23. Båve U, Nordmark G, Lövgren T, Rönnelid J, Cajander S, Eloranta ML, Alm GV, Rönnblom L: Activation of the type I interferon system in primary Sjögren's syndrome: a possible etiopathogenic mechanism. Arthritis Rheum 2005, 52:1185-1195.

24. Gottenberg JE, Cagnard N, Lucchesi C, Letourneur F, Mistou S, Lazure T, Jacques S, Ba N, Ittah M, Lepajolec C, Labetoulle M, Ardizzone M, Sibilia J, Fournier C, Chiocchia G, Mariette X: Activation of IFN pathways and plasmacytoid dendritic cell recruitment in target organs of primary Sjögren's syndrome. Proc Natl Acad Sci U S A 2006, 103:2770-2775.

25. Wildenberg ME, van Helden-Meeuwsen CG, van de Merwe JP, Drexhage HA, Versnel MA: Systemic increase in type I interferon activity in Sjögren's syndrome: a putative role for plasmacytoid dendritic cells. Eur I Immunol 2008, 38:2024-2033.

26. Lövgren T, Eloranta ML, Kastner B, Wahren-Herlenius M, Alm GV, Rönnblom L: Induction of interferon-alpha by immune complexes or liposomes containing systemic lupus erythematosus autoantigen- and Sjögren's syndrome autoantigen-associated RNA. Arthritis Rheum 2006, 54:1917-1927.

27. Ittah M, Miceli-Richard C, Gottenberg JE, Lavie F, Lazure T, Ba N, Sellam J, Lepajolec C, Mariette X: B cell-activating factor of the tumor necrosis factor family (BAFF) is expressed under stimulation by interferon in salivary gland epithelial cells in primary Sjögren's syndrome. Arthritis Res Ther 2006, 8:R51.

28. Shiozawa S, Morimoto I, Tanaka Y, Shiozawa K: A preliminary study on the interferon-alpha treatment for xerostomia of Sjögren's syndrome. $\mathrm{Br}$ J Rheumatol 1993, 32:52-54.

29. Ferraccioli GF, Salaffi F, De Vita S, Casatta L, Avellini C, Carotti M, Beltrami CA, Cervini C, Bartoli E: Interferon alpha-2 (IFNa2) increases lacrimal and salivary function in Sjögren's syndrome patients. Preliminary results of an open pilot trial versus OH-chloroquine. Clin Exp Rheumatol 1996, 14:367-371.

30. Shiozawa S, Tanaka Y, Shiozawa K: Single-blinded controlled trial of lowdose oral IFN-alpha for the treatment of xerostomia in patients with Sjögren's syndrome. J Interferon Cytokine Res 1998, 18:255-262.

31. Ship JA, Fox PC, Michalek JE, Cummins MJ, Richards AB: Treatment of primary Sjögren's syndrome with low-dose natural human interferonalpha administered by the oral mucosal route: a phase II clinical trial. IFN Protocol Study Group. J Interferon Cytokine Res 1999, 19:943-951.

32. Cummins MJ, Papas A, Kammer GM, Fox PC: Treatment of primary Sjögren's syndrome with low-dose human interferon alfa administered by the oromucosal route: combined phase III results. Arthritis Rheum 2003, 49:585-593.

33. Smith JK, Siddiqui AA, Modica LA, Dykes R, Simmons C, Schmidt J, Krishnaswamy GA, Berk SL: Interferon-alpha upregulates gene expression of aquaporin-5 in human parotid glands. J Interferon Cytokine Res 1999, 19:929-935,

34. Mariette X: Therapeutic potential for B-cell modulation in Sjögren's 
syndrome. Rheum Dis Clin North Am 2008, 34:1025-1033.

35. Pijpe J, van Imhoff GW, Spijkervet FKL, Roodenburg JLN, Wolbink GJ, Mansour $\mathrm{K}$, Vissink A, Kallenberg CGM, Bootsma H: Rituximab treatment in patients with primary Sjögren's syndrome. Arthritis Rheum 2005, 52:2740-2750.

36. Meijer JM, Pijpe J, Vissink A, Kallenberg CGM, Bootsma H: Treatment of primary Sjögren's syndrome with rituximab: extended follow-up, safety and efficacy of retreatment. Ann Rheum Dis 2009, 68:284-285.

37. Pijpe J, Meijer JM, Bootsma H, van der Wal JE, Spijkervet FKL, Kallenberg CGM, Vissink A, Ihrler S: Clinical and histologic evidence of salivary gland restoration supports the efficacy of rituximab treatment in Sjögren's syndrome. Arthritis Rheum 2009, 60:3251-3256.

38. Devauchelle-Pensec V, Pennec Y, Morvan J, Pers J-O, Daridon C, Jousse-Joulin S, Roudaut A, Jamin C, Renaudineau Y, Quintin Roué I, Cochener B, Youinou P, Saraux A: Improvement of Sjögren's syndrome after two infusions of rituximab (anti-CD20). Arthritis Rheum 2007, 57:310-317.

39. Dass S, Bowman SJ, Vital EM, Ikeda K, Pease CT, Hamburger J, Richards A, Rauz S, Emery P: Reduction of fatigue in Sjögren's syndrome with rituximab: results of a randomised, double-blind, placebo-controlled pilot study. Ann Rheum Dis 2008, 67:1541-1544.

40. Meijer JM, Meiners PM, Vissink A, Spijkervet FKL, Abdulahad W, Kamminga N, Brouwer E, Kallenberg CGM, Bootsma H: Effectiveness of rituximab treatment in primary Sjögren's syndrome. A randomized double-blind placebo-controlled trial. Arthritis Rheum 2010, 62:960-968.

41. Lavie F, Miceli-Richard C, Ittah M, Sellam J, Gottenberg JE, Mariette X: Increase of $B$ cell-activating factor of the TNF family (BAFF) after rituximab treatment: insights into a new regulating system of BAFF production. Ann Rheum Dis 2007, 66:700-703.

42. Pers J-O, Devauchelle V, Daridon C, Bendaoud B, Le Berre R, Bordron A, Hutin P, Renaudineau Y, Dueymes M, Loisel S, Berthou C, Saraux A, Youinou P: BAFF-modulated repopulation of B lymphocytes in the blood and salivary glands of rituximab-treated patients with Sjögren's syndrome. Arthritis Rheum 2007, 56:1464-1477.
43. Abdulahad WH, Meijer JM, Kroese FGM, Meiners PM, Vissink A, Spijkervet FKL, Kallenberg CGM, Bootsma H: B-cell reconstitution and T-helper-cell balance after rituximab treatment of active primary Sjögren's syndrome. Arthritis Rheum 2011, in press.

44. Devauchelle-Pensec V, Cagnard N, Pers JO, Youinou P, Saraux A, Chiocchia G: Gene expression profile in the salivary gland of primary Sjögren syndrome patients, before and after treatment with Rituximab. Arthritis Rheum 2010, 62:2262-2271.

45. Steinfeld SD, Tant L, Burmester GR, Teoh NK, Wegener WA, Goldenberg DM Pradier O: Epratuzumab (humanised anti-CD22 antibody) in primary Sjögren's syndrome: an open-label phase I/II study. Arthritis Res Ther 2006, 8:R129.

46. Groom J, Kalled SL, Cutler AH, Olson C, Woodcock SA, Schneider P, Tschopp J Cachero TG, Batten M, Wheway J, Mauri D, Cavill D, Gordon TP, Mackay CR, Mackay F: Association of BAFF/BLyS overexpression and altered B cell differentiation with Sjögren's syndrome. J Clin Invest 2002, 109:59-68.

47. Mariette X, Roux S, Zhang J, Bengoufa D, Lavie F, Zhou T, Kimberly R: The level of BLyS (BAFF) correlates with the titre of autoantibodies in human Sjögren's syndrome. Ann Rheum Dis 2003, 62:168-171.

48. Lavie F, Miceli-Richard C, Quillard J, Roux S, Leclerc P, Mariette X: Expression of BAFF (BLyS) in T cells infiltrating labial salivary glands from patients with Sjögren's syndrome. J Pathol 2004, 202:496-502.

49. Routsias JG, Tzioufas AG: Autoimmune response and target autoantigens in Sjogren's syndrome. Eur J Clin Invest 2010, 40:1026-1036.

50. Pijpe J, KalkWW, Bootsma H, Spijkervet FK, Kallenberg CG, Vissink A: Progression of salivary gland dysfunction in patients with Sjogren's syndrome. Ann Rheum Dis 2007, 66:107-112.

doi:10.1186/ar3234

Cite this article as: Kallenberg CGM et al:: What have we learned from clinical trials in primary Sjögren's syndrome about pathogenesis? Arthritis Research \& Therapy 2011, 13:205. 